\title{
Ethanol Intake and Toxicity: In Search of New Treatments
}

\author{
Ingesta de Etanol y Toxicidad: En Búsqueda de Nuevos Tratamientos
}

Cristian Sandoval ${ }^{1,2,3}$; Bélgica Vásquez ${ }^{4}$; Carlos Mandarim-de-Lacerda ${ }^{5}$ \& Mariano del Sol $^{1,6}$

SANDOVAL, C.; VÁSQUEZ, B.; MANDARIM-DE-LACERDA, C. \& DEL SOL, M. Ethanol intake and toxicity: In search of new treatments. Int. J. Morphol., 35(3):942-949, 2017.

SUMMARY: Prolonged alcohol consumption has consequences on the liver, producing necrotic precipitates and fibrosis, on the pancreas, causing the pancreatic acini to atrophy and destroying insulin-producing cells, and on the central nervous system (CNS), causing the gray and white matter in the frontal lobes of the brain and cerebellum to atrophy. Generally, alcohol is metabolized via oxidative pathways, where the enzymes alcohol dehydrogenase and aldehyde dehydrogenase participate during its metabolization in the liver and CNS, or via nonoxidative pathways during its metabolization in the pancreas. Ethanol metabolism can produce oxidative stress and tissue damage mediated by free radicals, causing morphological and functional alterations in the liver. In the pancreas, it can cause progressive and irreversible damage affecting the endocrine and exocrine functions, a result of the activation of the stellate cells, which are activated directly by alcohol, causing pancreatic fibrosis. In the CNS ethanol can bind directly to proteins, nucleic acids and phospholipids to develop its pathogenesis. The effects produced by alcohol can be counteracted by supplementation with antioxidants, which reduce the inflammation and areas of focal necrosis in the liver, inhibit the activation of pancreatic stellate cells, and reduce oxidative stress in the CNS. Additionally, in order to reduce the negative effects associated with alcohol consumption, recent studies have suggested the administration of antioxidants as a treatment strategy.

KEY WORDS: Antioxidants; Ethanol; Liver; Pancreas; Central nervous system.

\section{INTRODUCTION}

Ethanol ranks first on the list of abused drugs in many parts of the world and Chile is no exception. Alcoholism is a chronic disorder, with psychological and physical addiction that affects around $10 \%$ of the world population (Hegde et al., 2000). It has been reported that alcohol abuse and dependency occupy third place in the risks to human health in the world (World Health Organization, 2011), where Latin American countries and those belonging to the former Soviet Union represent more than double the risk for alcohol consumption than the global average (González \& Alcalá, 2005).

Chile is one of the countries with the highest alcohol intake, and Santiago, its capital, was first in Latin America for death by liver cirrhosis in 1968, while mortality due to alcohol consumption was 9.8 \% in 2009 (Medina, 1980; Vargas, 2009).

Ethanol is harmful to the human body, able to cause toxicity and death when ingested in excessive amounts. Ethanol metabolism produces alcoholic fatty liver, alcoholic hepatitis or cirrhosis (García Gutiérrez et al., 2004; Arias, 2005), chronic pancreatitis and/or atrophy of the gray and white matter of the frontal lobes of the brain and cerebellum and limbic structures (Mukamal, 2004). However, it must be noted that the appearance of pathology as a result of alcohol consumption will depend on several factors, including the amount and quality of the alcohol consumed and consumption patterns (Rehm et al., 2010a; 2010b).

\footnotetext{
${ }^{1}$ Programa de Doctorado en Ciencias Morfológicas, Universidad de La Frontera, Temuco, Chile.

${ }^{2}$ Centro de Investigación en Morfología Aplicada (CIMA), Facultad de Odontología, Universidad de La Frontera, Temuco, Chile.

${ }^{3}$ CONICYT-PCHA/Doctorado Nacional/2015-21150991.

${ }^{4}$ Universidad de Tarapacá, Arica, Chile.

${ }^{5}$ Laboratorio de Morfometría, Metabolismo y Enfermedades Cardiovasculares, Centro Biomédico, Instituto de Biología, Universidade do Estado do Rio de Janeiro, Rio de Janeiro, Brasil.

${ }^{6}$ Centro de Excelencia en Estudios Morfológicos y Quirúrgicos (CEMyQ), Universidad de La Frontera, Temuco, Chile. Proyecto DIUFRO DI16-0132. Proyecto DIUFRO-FAPERJ FPJ15-0013.

CONICYT-PCHA/Doctorado Nacional/2015-21150991.
} 
Physiopathology of ethanol in the liver. The effects of alcohol on tissues depend on its concentration in the blood, which is determined by the speed at which it is absorbed, distributed, metabolized and excreted from the body, as well as by environmental factors and genetic variations in the main enzymes that metabolize alcohol (Zakhari, 2006). Generally, alcohol is metabolized via oxidative pathways, where the enzymes alcohol dehydrogenase (ADH) and aldehyde dehydrogenase (ALDH) participate, or via nonoxidative pathways.

Alcohol is metabolized largely by the liver, since this contains several high affinity enzyme systems that can oxidize alcohol. On the one hand, the oxidative pathways of ethanol metabolization include ADH, cytochrome P450 2E1 (CYP2E1) and catalase. Around $90 \%$ of the ethanol is metabolized in the hepatocytes, where it is converted into acetaldehyde by the ADH, whereas when the capacity of the ADH to metabolize the alcohol is saturated, isoenzymes of cytochrome P450 assume the role of metabolizing this compound to acetaldehyde in the liver and other tissues like the brain (Hansson et al., 1990), where ADH activity is low. Also, the catalase located in peroxisomes can oxidize ethanol in the presence of NADPH or the enzyme xanthine oxidase. This acetaldehyde, resulting from ethanol oxidation, is converted into acetate and NADPH in a reaction catalyzed by ALDH in the mitochondria (Lieber, 2004; Zakhari; Zintzaras et al., 2006).

Acetaldehyde, resulting from ethanol oxidation, is a reactive and highly toxic by-product that contributes to tissue damage, the formation of reactive oxygen species (ROS) and an imbalance in the redox potential (NAD/NADH). It also forms protein aggregates in hepatocytes, reducing the secretion of proteins and promoting hepatomegaly, with dopamine to generate salsolinol, which can contribute to alcohol dependency, and binds with the DNA to form carcinogenic products like 1, $\mathrm{N}^{2}$-propano-2'-desoxyguanosine (Tuma \& Casey, 2003).

Ethanol metabolism can cause oxidative stress and tissue damage mediated by free radicals, causing morphological and functional alterations in the liver. Lieber (1988), Yip \& Burt (2006), Albano (2008) and Conde de la Rosa et al. (2008) report that ethanol metabolism activates xanthine oxidase, CYP2E1 proteins and the NADPH oxidase complex, increasing the concentrations of ROS, promoting lipid peroxidation, increased catabolism of hepatic vitamin A and progression of liver damage.

Regardless of the origin, ROS formation has numerous detrimental effects. It has been reported that ethanol promotes the formation of ROS within the mitochondria and reduces the concentration of reduced mitochondrial glutathione (GSH), promoting increased susceptibility of this organelle to oxidative damage (Bailey \& Cunningham, 2002; Fernández-Checa \& Kaplowitz, 2005). Also, ROS stimulate the release of TNF- $\alpha$, which can contribute to tissue damage and scar tissue formation in the liver. It has also been described that ROS can interact with lipids, proteins and DNA in a process called peroxidation, leading to the production of malondialdehyde (MDA) and 4-hydroxynonenal (HNE) (Zakhari). Peroxidation increases the permeability of the inner mitochondrial membrane and deterioration of mitochondrial oxidative phosphorylations (Bailey \& Cunningham; Hoek et al., 2002; Zakhari), which leads to ballooning degeneration and necrotic precipitates in the hepatocytes, whereas the release of cytochrome $\mathrm{c}$, a result of the increase in mitochondrial permeability, induces apoptosis (Zhao et al., 1997; Green \& Kroemer, 2004; Ronis et al., 2010). Additionally, the alteration in the distribution of electrical charges in the membranes generates reduced levels of cellular ATP and promotes necrosis. Moreover, the deterioration of hepatic antioxidant defenses and the alteration of iron homeostasis can contribute to the oxidative damage related to the hepatotoxicity of alcohol (Albano, 2006). Morphologically, alcoholic liver disease (ALD) includes a broad spectrum of anatomical characteristics that range from steatosis with minor lesions to more advanced liver damage, including steatohepatitis and fibrosis/cirrhosis, where around $15 \%$ of patients with established alcoholic cirrhosis develop hepatocellular carcinoma (Yip \& Burt). It is currently accepted that the progression of ALD to a more serious disease is a multi-factor process that involves several genetic, nutritional and environmental factors (Day, 2006).

The effects produced by alcohol in the liver can be counteracted by the antioxidant defense of the hepatocyte, which induces enzymatic mechanisms like superoxide dismutase, catalase, glutathione peroxidase and glutathione reductase (Zelko et al., 2002; Chang et al., 2005) as well as other non-enzymatic mechanisms. These non-enzymatic defense mechanisms include: GSH, which is almost exclusively in its reduced form and detoxifies the ROS produced on the mitochondrial electronic transport chain; metal-binding proteins, which help both iron and copper remain in a non-reactive state and avoid the formation of hydroxyl radicals; and vitamins $\mathrm{C}$ and $\mathrm{E}$ and the carotenoids that deactivate the free radicals (Nieto et al., 2002; Nieto, 2007). Therefore, studies conducted by Nanji et al. (2001) demonstrated the prevention of lipid peroxidation by means of animal supplementation with antioxidants, reducing the inflammation and areas of focal necrosis. 
Physiopathology of ethanol in the pancreas. Ethanol is the most frequent etiology of chronic pancreatitis, and is related to consumption level. Only a small percentage of alcoholics develop the disease, which suggests a special susceptibility for its development is required. Previous in vitro and in vivo studies have indicated that the detrimental effects of ethanol in the pancreas is likely due to the toxic effects of ethanol metabolism via the oxidative pathways, generating acetaldehyde metabolites, or via non-oxidative pathways, producing fatty acid ethyl esters.

The pancreas has the enzymatic capacity to metabolize ethanol via two pathways (Haber et al., 1998, 2004; Gukovskaya et al., 2002). The main metabolic pathway in the pancreas is the non-oxidative, which involves an esterification reaction of fatty acids with ethanol, resulting in the formation of fatty acid ethyl esters (FAEEs), which increase the oxidative stress and the fragility of lysosomal membranes and zymogen granules, which contain lysosomal and digestive enzymes, respectively, facilitating early intracellular enzyme activation. In this sense, it has been reported that the instability of the lysosomal membrane can be mediated by cholesterol esters (Wilson et al., 1992) and FAEEs (Haber et al., 1993), substances that accumulate in the pancreas after chronic ethanol consumption (Lange \& Sobel, 1983; Wilson et al., 1982), whereas the instability of zymogen granules is considered to be the result of the loss of glycoprotein-2 (GP-2), which is important for the shape and stability of the granules (Apte et al., 1997). The mechanisms by which the FAEEs exert their toxic effects include: direct interaction of the compounds with cell membranes (Hungund et al., 1988), stimulation of the cholesterol ester synthesis by transesterification (Lange, 1982), and release of free fatty acids by hydrolysis of FAEEs, a process believed to contribute to the mitochondrial damage induced by FAEEs (Lange). Currently, it is known that the activity of FAEE synthases is greater in the pancreas than in the liver; however, further study is required (Wilson \& Apte, 2003). The second is the oxidative pathway, which activates the stellate cells, leading to pancreatic fibrosis. It has demonstrated that both human and rat stellate cells are activated directly by ethanol in clinically relevant concentrations that go from $10 \mathrm{mM}$ (social consumption) to $50 \mathrm{mM}$ (intense ethanol consumption) (Apte et al., 2000; Masamune et al., 2010). This pancreatic metabolization pathway for ethanol includes ADH3, a saturable form of the ADH enzyme with low affinity and high $\mathrm{K}_{\mathrm{m}}$ for ethanol, cytochrome P450 2E1 (CYP231), the expression of which is induced by the ethanol ingestion, and catalase. The latter pathway produces acetaldehyde, which activates the stellate cells leading to pancreatic fibrosis. It has been described that ethanol, acetaldehyde and metabolites of the nonoxidative pathway increase cytokine levels, promoting necroinflammation and stimulation of the stellate cells (Omary et al., 2007; Witt et al., 2007), which synthesize extracellular matrix proteins and enzymes that degrade the matrix (matrix metalloproteinases [MMP]). Recent studies indicate that ethanol, acetaldehyde and FAEE induce the expression of NF- $\mathrm{\kappa B}$ and AP-1, transcription factors that regulate cytosine expression (Gukovskaya et al.).

During a pancreas injury, the pancreatic stellate cells can be activated by profibrogenic growth factors, such as transforming growth factor beta (TGF- $\beta$ ), proliferative growth factors, like platelet-derived growth factor (PDGF), proinflammatory cytokines and oxidative stress (Apte \& Wilson). This state of activation is characterized by a loss of vitamin A, alpha smooth muscle actin ( $\alpha$-SMA) production, and increased production of extracellular matrix proteins such as collagens I and III, fibronectin and laminin. In addition, they produce increased amounts of MMP-2 and its inhibiter, tissue inhibiter of metalloproteinase-2 (TIMP2 ), causing the fibrogenic response to proliferate due to destruction of the collagen in the basal membrane (collagen IV) and deposition of fibrillar collagen (collagen I) (Phillips et al., 2003).

In the pancreas, ethanol can cause progressive and irreversible damage affecting the endocrine and exocrine functions of this organ. In this sense, Apte et al. (1997) and Stevens et al. (2004) reported that ethanol reduces pancreatic secretions, leads to increases in the viscosity of pancreatic secretions, lowers the citrate concentration in the pancreatic fluid, a known predisposing factor in crystal formation, and produces proteins that increase the formation of stones, such as pancreatic stone protein (PSP) and glycoprotein-2 (GP2 ), which produces mechanical obstruction, interference with enzyme secretion and intracellular activation of pancreatic enzymes. A histological characteristic of chronic alcoholic pancreatitis is pancreatic fibrosis. In fact, the histological findings show fibrosis, atrophy of the pancreatic acini, chronic inflammation, distortion of the pancreatic ducts with areas of stenosis and characteristic destruction of insulinproducing cells (b cells) and glucagon-producing cells (a cells) (Witt et al.).

From the clinical point of view, type 2 diabetes mellitus can develop as a result of chronic pancreatitis due to ethanol. According to the American Diabetes Association, it is characterized by the destruction of insulin-producing cells and glucagon-producing cells (Witt et al.). The association between ethanol consumption and diabetes mellitus was demonstrated at the beginning of 1971 by Phillips \& Safrit (1971). Later, Selby et al. (1987) indicated that ethanol consumption can influence fasting plasma glucose levels after the analysis of 434 pairs of non-diabetic 
adult female twins. These results imply that ethanol could affect fasting and postprandial glycemic controls and therefore could be a risk factor for type 2 diabetes.

Nevertheless, there have also been studies with negative or opposite results that explain the relationship between ethanol consumption and the development of type 2 diabetes mellitus. Ethanol consumptions of $5-14.9 \mathrm{~g} /$ day and more than $15 \mathrm{~g} /$ day were associated with a decrease in the relative risk of diabetes mellitus in women (Stampfer $e t$ al., 1988). In a later study by Wannamethee et al. (2003), they indicated that moderate ethanol consumption may be associated with a lower risk of diabetes mellitus type 2 among women 25 to 42 years of age in comparison with lifelong abstinence, whereas excessive ethanol consumption showed a significant increase of the risk of developing diabetes. Similarly, a moderate amount of ethanol consumption was associated with a lower risk of developing diabetes mellitus in male health care professionals (Rimm et al., 1995). The reduction of the incidence of type 2 diabetes through moderate ethanol consumption was also observed in seniors (Djoussé et al., 2007). The aforementioned results suggest that sex and the amount of ethanol consumed are factors that can influence the development of diabetes mellitus.

Physiopathology of ethanol in the central nervous system. There is a neural system in the mammalian brain that regulates the effects of natural stimuli, allowing survival of the species. This system, known as a reinforcement-reward cycle, is also affected by other types of non-natural stimuli, such as drug abuse (Roberts \& Koob, 1997).

The enzymes involved in liver ethanol metabolism have also been linked to ethanol metabolism in the brain. First of all, the role of ADH in the brain ethanol metabolism remains unclear, since although the presence of brain ADH has been observed, it has been reported that ethanol is not a good substrate in this organ (Beisswenger et al., 1985; Kerr et al., 1989). Other studies have shown an increase in cytochrome $\mathrm{P} 450$ in the brains of rats treated with ethanol (Warner \& Gustafsson, 1994), observing induction of nerve cells and support cells due to the action of ethanol in the cerebellum, cerebral cortex, thalamus and hippocampus (Sohda et al., 1993; Tindberg \& Ingelman-Sundberg, 1996; Upadhya et al., 2000). Additionally, Zimatkin et al. (2006) reinforced in rats and mice the possibility that cytochrome P450 is involved in the brain ethanol metabolism. Also, catalase can participate in the production of acetaldehyde from the ethanol present in the brain. Thus, Gill et al. (1992) were able to prevent the non-enzymatic formation of acetaldehyde and demonstrate the production of acetaldehyde from the reaction between ethanol and catalase in rat brains.
Acetaldehyde, a toxic by-product of ethanol metabolization, has been described as a causative agent of the alterations to the CNS during its consumption (Hunt, 1996; Bergamaschi et al., 1988; Zimatkin \& Deitrich, 1997; Thadani \& Truitt, 1977; Heap et al., 1995). Its consequences can be divided into two categories: the first is the direct binding to proteins (Jennett et al., 1987; McKinnon et al., 1987; Nakamura et al., 2003; Zimatkin et al., 1992), nucleic acids (Wang et al., 2000) and phospholipids (Trudell et al., 1990, 1991; Kenney, 1982, 1984), and the second is the indirect action of ethanol oxidation, which produces inhibition of the endogenous production of acetaldehyde.

Recently, researchers have proposed that acetaldehyde can compete with MDA or HNE, products of aldehyde resulting from lipid peroxidation. These aldehydes can also inhibit ALDH activity (Luckey et al., 1999; Mark et al., 1997; Meyer et al., 2004; Murphy et al., 2003), resulting in an increase in acetaldehyde levels as well as these toxic aldehydes. However, these effects produced by ethanol in the CNS can be counteracted by polyphenolic antioxidants, such as the contents in green tea, or drugs synthesized from amino acids, like acetylcysteine (NAC) (Aydin et al., 2002; Skrzydlewska et al., 2005).

Role of antioxidants in ethanol consumption. It is known that alcohol can partially cover the body's energy needs by dislodging the remaining nutrients in the diet. However, they generally do not contain proteins, vitamins, minerals or other nutrients; therefore, regular ethanol consumption can cause a nutritional deficit (Lieber, 1980). As indicated previously, fibrosis and liver cirrhosis are frequent complications of alcoholism that appear although the diets are high in protein and fats and supplemented with vitamins and minerals; therefore, from a therapeutic point of view, this procedure is not totally successful for the prevention of cirrhosis in alcoholics (Lieber, 1985). Thus, chronic ethanol consumption generates a secondary malnutrition due to damage to the digestion and nutrient absorption.

Vitamin A levels in the liver are reduced with ethanol consumption (Ahmed et al., 1994). Nevertheless, this reduction cannot be explained solely by an alteration in intake, absorption or changes in the serum retinol levels or its serum-transporting protein. An increased mobilization or catabolism of hepatic vitamin A have been suggested as possible mechanisms (Lieber, 1988). It is currently known that antioxidants can be used as a treatment strategy in various pathologies, including ethanol consumption. It has been found that activation of pancreatic stellate cells is inhibited when these are incubated with antioxidants (Apte et al., 2000; McCarroll et al., 2006). This is why vitamin A, 
an antioxidant, may represent a potential treatment strategy for the damage produced by ethanol.

According to what has been previously suggested, it seems plausible to treat alcoholics by administering vitamin A to compensate for the effects of ethanol. However, several factors complicate vitamin A therapy in alcoholism treatment. It is difficult to assess the amount of vitamin A that is in fact stored in the tissues, because what is in the blood does not necessarily reflect the levels in the liver. High doses of vitamin A are toxic. Habitual doses of vitamin A are even potentially detrimental in alcoholics who continue to consume alcoholic drinks, since ethanol boosts the toxicity of vitamin A (Lieber, 2003).

In order to avoid or reduce the problems associated with vitamin A therapy, the treatment of alcoholics has been considered using the precursor to vitamin $\mathrm{A}, \beta$-carotene. This precursor is a carotenoid that acts as an antioxidant when eliminating free radicals (Fukuzawa et al., 1998). It has been found that a liver deficiency of vitamin A induced by ethanol can be corrected by $30-60 \mathrm{mg}$ of $\beta$-carotene supplements per day (Ahmed et al.). Subsequent investigations suggest that supplementation with $\beta$-carotenes prevent ethanolinduced liver damage and increase the concentration of glutathione reduced in rats (Lin et al., 2009). Also, a $\beta$ carotene concentrate has been linked to an improvement in insulin resistance in overweight children (Canas et al., 2012).

Nevertheless, although $\beta$-carotene is thought to be less dangerous, it can also have toxic effects on the liver of patients who continue consuming ethanol (Leo et al., 1992). In addition, b-carotene increases the risk of lung cancer in smokers (Alpha-Tocopherol, Beta Carotene Cancer Prevention Study Group, 1994). This is important because most smokers also drink ethanol, and researchers have discovered that the increased risk of lung cancer after therapy with b-carotene is related to concurrent ethanol consumption in smokers (Albanes et al., 1996). Therefore, treatment with b-carotene in these patients must be administered with caution.

However, other antioxidants have been evaluated for the treatment of ethanol consumption. In this sense, it has been described that both cinnamic acid and syringic acid suppress liver activity and/or protein expression of CYP2E1, ADH, NADPH oxidase, iNOS, COX-2 and NF- $\kappa$ B, improving the inflammatory and oxidative damage produced by ethanol (Yan et al., 2016). It has also been reported that hydroxysafflor yellow A (HSYA) can prevent ethanolinduced liver damage by suppressing TGF- $\beta 1$ expression and improving the antioxidant capacity of the liver ( $\mathrm{He}$ et al., 2015). By contrast, baicalin can alleviate ethanol-induced liver damage in rats, probably due to its antioxidant, antiinflammatory properties and the activation of Shh, which plays an important role in the morphogenesis of tissues and liver repair (Wang et al., 2016)

In addition, the effects of ethanol on the CNS can be counteracted by polyphenolic antioxidants, which decrease the enzymatic activities of brain superoxide dismutase, glutathione peroxidase, glutathione reductase and catalase, causing a reduction in oxidative stress and protection of the CNS (Skrzydlewska et al.), or by drugs synthesized from amino acids, which contribute to the regeneration of glutathione by direct reaction with hydroxyl radicals (Aydin et al.).

\section{CONCLUSIONS}

This review highlights the studies that explain the metabolism of ethanol, the pathogenesis of alcohol toxicity and its possible therapeutic targets. Currently, the oral administration of antioxidants offers an alternative therapy to the traditional treatments for alcohol consumption. However, despite all the advances that have been made in clarifying adverse events caused by excessive alcohol consumption, the molecular mechanisms through which antioxidant therapy has played a role have not yet been satisfactorily resolved. In this way, future studies should clarify more efficiently the relationship between chronic ethanol consumption and antioxidants in order to find more effective therapies.

SANDOVAL, C.; VÁSQUEz, B.; MANDARIM-DELACERDA, C. \& DEL SOL, M. Int. J. Morphol., 35(3):942949, 2017.

RESUMEN: El consumo prolongado de alcohol tiene consecuencias en hígado, produciendo precipitados necróticos y fibrosis; en páncreas, provocando atrofia del acino pancreático y destrucción de las células productoras de insulina, y en Sistema Nervioso Central (SNC) generando atrofia de la sustancia gris y blanca en lóbulos frontales del cerebro y cerebelo. En general, el metabolismo del alcohol se consigue mediante las vías oxidativas, donde participan las enzimas alcohol-deshidrogenasa y aldehído deshidrogenasa durante su metabolización en hígado y SNC; o bien, mediante las vías no oxidativas durante su metabolización en páncreas. El metabolismo del etanol es capaz de producir estrés oxidativo y daño tisular mediado por radicales libres, causando alteraciones morfológicas y funcionales del hígado; en el páncreas, puede causar daño progresivo e irreversible afectando las funciones endocrinas y exocrinas de este órgano producto de la activación de las células estrelladas que son activadas directamente por el alcohol generando fibrosis pancreática; mientras que, en SNC 
se puede unir directamente a proteínas, ácidos nucleicos y fosfolípidos para desarrollar su patogenia. Los efectos producidos por el alcohol pueden contrarrestarse mediante la suplementación con antioxidantes, que reducen la inflamación y las zonas de necrosis focal en el hígado, inhiben la activación de células pancreáticas estrelladas, y reducen el estrés oxidativo en SNC. Asimismo, para reducir los efectos negativos asociados al consumo de alcohol, estudios recientes han propuesto la administración de antioxidantes como estrategia terapéutica.

PALABRAS CLAVE: Antioxidantes; Etanol; Hígado; Páncreas; Sistema nervioso central.

\section{REFERENCES}

Ahmed, S.; Leo, M. A. \& Lieber, C. S. Interactions between alcohol and beta-carotene in patients with alcoholic liver disease. Am. J. Clin. Nutr., 60(3):430-6, 1994.

Albanes, D.; Heinonen, O. P.; Taylor, P. R.; Virtamo, J.; Edwards, B. K.; Rautalahti, M.; Hartman, A. M.; Palmgren, J.; Freedman, L. S.; Haapakoski, J.; Barrett, M. J.; Pietinen, P.; Malila, N.; Tala, E.; Liippo, K.; Salomaa, E. R.; Tangrea, J. A.; Teppo, L.; Askin, F. B.; Taskinen, E.; Erozan, Y.; Greenwald, P. \& Huttunen J. K. Alpha-Tocopherol and beta-carotene supplements and lung cancer incidence in the alphatocopherol, beta-carotene cancer prevention study: effects of base-line characteristics and study compliance. J. Natl. Cancer Inst., 88(21):156070, 1996.

Albano, E. Alcohol, oxidative stress and free radical damage. Proc. Nutr. Soc., 65(3):278-90, 2006.

Albano, E. Oxidative mechanisms in the pathogenesis of alcoholic liver disease. Mol. Aspects Med., 29(1-2):9-16, 2008.

Alpha-Tocopherol, Beta Carotene Cancer Prevention Study Group. The effect of vitamin $\mathrm{E}$ and beta carotene on the incidence of lung cancer and other cancers in male smokers. N. Engl. J. Med., 330(15):1029-35, 1994.

Apte, M. V. \& Wilson, J. S. Stellate cell activation in alcoholic pancreatitis. Pancreas, 27(4):316-20, 2003.

Apte, M. V.; Norton, I. D.; Haber, P. S.; Korsten, M. A.; McCaughan, G. W.; Pirola, R. C. \& Wilson, J. S. Chronic ethanol administration decreases rat pancreatic GP2 content. Biochim. Biophys. Acta, 1336(1):89-98, 1997.

Apte, M. V.; Phillips, P. A.; Fahmy, R. G.; Darby, S. J.; Rodgers, S. C.; McCaughan, G. W.; Korsten, M. A.; Pirola, R. C.; Naidoo, D. \& Wilson, J. S. Does alcohol directly stimulate pancreatic fibrogenesis? Studies with rat pancreatic stellate cells. Gastroenterology, 118(4):780-94, 2000.

Arias, D. R. Reacciones fisiológicas y neuroquímicas del alcoholismo. Diversitas, 1(2):138-47, 2005.

Aydin, S.; Ozaras, R.; Uzun, H.; Belce, A.; Uslu, E.; Tahan, V.; Altug, T.; Dumen, E. \& Senturk, H. N-acetylcysteine reduced the effect of ethanol on antioxidant system in rat plasma and brain tissue. Tohoku J. Exp. Med., 198(2):71-7, 2002.

Bailey, S. M. \& Cunningham, C. C. Contribution of mitochondria to oxidative stress associated with alcoholic liver disease. Free Radic. Biol. Med., 32(1):11-6, 2002.

Beisswenger, T. B.; Holmquist, B. \& Vallee, B. L. chi-ADH is the sole alcohol dehydrogenase isozyme of mammalian brains: implications and inferences. Proc. Natl. Acad. Sci. U. S. A., 82(24):8369-73, 1985.

Bergamaschi, S.; Govoni, S.; Rius, R. A. \& Trabucchi, M. Acute ethanol and acetaldehyde administration produce similar effects on L-type calcium channels in rat brain. Alcohol, 5(4):337-40, 1988.

Canas, J. A.; Damaso, L.; Altomare, A.; Killen, K.; Hossain, J. \& Balagopal,
P. B. Insulin resistance and adiposity in relation to serum b-carotene levels. J. Pediatr., 161(1):58-64.e1-2, 2012.

Chang, P.; Cheng, E.; Brooke, S. \& Sapolsky, R. Marked differences in the efficacy of post-insult gene therapy with catalase versus glutathione peroxidase. Brain Res., 1063(1):27-31, 2005.

Conde de la Rosa, L.; Moshage, H. \& Nieto, N. Estrés oxidativo hepatocitario y hepatopatía alcohólica. Rev. Esp. Enferm. Dig., 100(3): 156-63, 2008.

Day, C. P. Genes or environment to determine alcoholic liver disease and non-alcoholic fatty liver disease. Liver Int., 26(9):1021-8, 2006.

Djoussé, L.; Biggs, M. L.; Mukamal, K. J. \& Siscovick, D. S. Alcohol consumption and type 2 diabetes among older adults: the Cardiovascular Health Study. Obesity (Silver Spring), 15(7):1758-65, 2007.

Fernández-Checa, J. C. \& Kaplowitz, N. Hepatic mitochondrial glutathione: transport and role in disease and toxicity. Toxicol. Appl. Pharmacol., 204(3):263-73, 2005.

Fukuzawa, K.; Inokami, Y.; Tokumura, A.; Terao, J. \& Suzuki, A. Rate constants for quenching singlet oxygen and activities for inhibiting lipid peroxidation of carotenoids and alpha-tocopherol in liposomes. Lipids, 33(8):751-6, 1998.

García Gutiérrez, E.; Lima Mompó, G.; Aldana Vilas, L.; Casanova Carri1lo, P. \& Feliciano Álvarez, V. Alcoholismo y sociedad, tendencias actuales. Rev. Cuba. Med. Mil., 33(3), 2004. Disponible en: http:// scielo.sld.cu/scielo.php?script=sci_arttext\&pid=S0138$65572004000300007 \& \operatorname{lng}=\mathrm{es}$

Gill, K.; Menez, J. F.; Lucas, D. \& Deitrich, R. A. Enzymatic production of acetaldehyde from ethanol in rat brain tissue. Alcohol. Clin. Exp. Res., 16(5):910-5, 1992.

González, R. \& Alcalá, J. Consumo de Alcohol y Salud Pública. Ciudad de México, Universidad Nacional Autónoma de México, 2005.

Green, D. R. \& Kroemer, G. The pathophysiology of mitochondrial cell death. Science, 305(5684):626-9, 2004.

Gukovskaya, A. S.; Mouria, M.; Gukovsky, I.; Reyes, C. N.; Kasho, V. N.; Faller, L. D. \& Pandol, S. J. Ethanol metabolism and transcription factor activation in pancreatic acinar cells in rats. Gastroenterology, 122(1):106-18, 2002.

Haber, P. S.; Apte, M. V.; Applegate, T. L.; Norton, I. D.; Korsten, M. A.; Pirola, R. C. \& Wilson, J. S. Metabolism of ethanol by rat pancreatic acinar cells. J. Lab. Clin. Med., 132(4):294-302, 1998.

Haber, P. S.; Apte, M. V.; Moran, C.; Applegate, T. L.; Pirola, R. C.; Korsten, M. A.; McCaughan, G, W. \& Wilson, J. S. Non-oxidative metabolism of ethanol by rat pancreatic acini. Pancreatology, 4(2):82-9, 2004.

Haber, P. S.; Wilson, J. S.; Apte, M. V. \& Pirola, R. C. Fatty acid ethyl esters increase rat pancreatic lysosomal fragility. J. Lab. Clin. Med., 121(6):759-64, 1993.

Hansson, T.; Tindberg, N.; Ingelman-Sundberg, M. \& Köhler, C. Regional distribution of ethanol-inducible cytochrome P450 IIE1 in the rat central nervous system. Neuroscience, 34(2):451-63, 1990.

He, Y.; Liu, Q.; Li, Y.; Yang, X.; Wang, W.; Li, T.; Zhang, W.; Cui, Y.; Wang, C. \& Lin, R. Protective effects of hydroxysafflor yellow A (HSYA) on alcohol-induced liver injury in rats. J. Physiol. Biochem., 71(1):69-78, 2015.

Heap, L.; Ward, R. J.; Abiaka, C.; Dexter, D.; Lawlor, M.; Pratt, O.; Thomson, A.; Shaw, K. \& Peters, T. J. The influence of brain acetaldehyde on oxidative status, dopamine metabolism and visual discrimination task. Biochem. Pharmacol., 50(2):263-70, 1995.

Hegde, A.; Veis, J. H.; Seidman, A.; Khan, S. \& Moore, J. Jr. High prevalence of alcoholism in dialysis patients. Am. J. Kidney Dis., 35(6):1039-43, 2000.

Hoek, J. B.; Cahill, A. \& Pastorino, J. G. Alcohol and mitochondria: a dysfunctional relationship. Gastroenterology, 122(7):2049-63, 2002.

Hungund, B. L.; Goldstein, D. B.; Villegas, F. \& Cooper, T. B. Formation of fatty acid ethyl esters during chronic ethanol treatment in mice. Biochem. Pharmacol., 37(15):3001-4, 1988.

Hunt, W. A. Role of acetaldehyde in the actions of ethanol on the brain--a review. Alcohol, 13(2):147-51, 1996. 
Jennett, R. B.; Sorrell, M. F.; Johnson, E. L. \& Tuma, D. J. Covalent binding of acetaldehyde to tubulin: evidence for preferential binding to the alphachain. Arch. Biochem. Biophys., 256(1):10-8, 1987.

Kenney, W. C. Acetaldehyde adducts of phospholipids. Alcohol. Clin. Exp. Res., 6(3):412-6, 1982.

Kenney, W. C. Formation of Schiff base adduct between acetaldehyde and rat liver microsomal phosphatidylethanolamine. Alcohol. Clin. Exp. Res., 8(6):551-5, 1984

Kerr, J. T.; Maxwell, D. S. \& Crabb, D. W. Immunocytochemistry of alcohol dehydrogenase in the rat central nervous system. Alcohol. Clin. Exp. Res., 13(6):730-5, 1989.

Lange, L. G. \& Sobel, B. E. Mitochondrial dysfunction induced by fatty acid ethyl esters, myocardial metabolites of ethanol. J. Clin. Invest., 72(2):724-31, 1983.

Lange, L. G. Nonoxidative ethanol metabolism: formation of fatty acid ethyl esters by cholesterol esterase. Proc. Natl. Acad. Sci. U. S. A., 79(13):3954-7, 1982.

Leo, M. A.; Kim, C.; Lowe, N. \& Lieber, C. S. Interaction of ethanol with beta-carotene: delayed blood clearance and enhanced hepatotoxicity. Hepatology, 15(5):883-91, 1992.

Lieber, C. S. Alcohol and the liver: metabolism of ethanol, metabolic effects and pathogenesis of injury. Acta Med. Scand. Suppl., 703:11-55, 1985.

Lieber, C. S. Alcohol, liver injury and protein metabolism. Pharmacol. Biochem. Behav., 13 Suppl. 1:17-30, 1980.

Lieber, C. S. Alcoholic fatty liver: its pathogenesis and mechanism of progression to inflammation and fibrosis. Alcohol, 34(1):9-19, 2004.

Lieber, C. S. Relationships between nutrition, alcohol use, and liver disease. Alcohol Res. Health, 27(3):220-31, 2003.

Lieber, C. S. The influence of alcohol on nutritional status. Nutr. Rev., 46(7):241-54, 1988

Lin, W. T.; Huang, C. C.; Lin, T. J.; Chen, J. R.; Shieh, M. J.; Peng, H. C.; Yang, S. C. \& Huang, C. Y. Effects of beta-carotene on antioxidant status in rats with chronic alcohol consumption. Cell Biochem. Funct., 27(6):344-50, 2009

Luckey, S. W.; Tjalkens, R. B. \& Petersen, D. R. Mechanism of inhibition of rat liver class 2 ALDH by 4-hydroxynonenal. Adv. Exp. Med. Biol., 463:71-7, 1999.

Mark, R. J.; Lovell, M. A.; Markesbery, W. R.; Uchida, K. \& Mattson, M. P. A role for 4-hydroxynonenal, an aldehydic product of lipid peroxidation, in disruption of ion homeostasis and neuronal death induced by amyloid beta-peptide. J. Neurochem., 68(1):255-64, 1997.

Masamune, A.; Satoh, A.; Watanabe, T.; Kikuta, K.; Satoh, M.; Suzuki, N.; Satoh, K. \& Shimosegawa, T. Effects of ethanol and its metabolites on human pancreatic stellate cells. Dig. Dis. Sci., 55(1):204-11, 2010.

McCarroll, J. A.; Phillips, P. A.; Santucci, N.; Pirola, R. C.; Wilson, J. S. \& Apte, M. V. Vitamin A inhibits pancreatic stellate cell activation: implications for treatment of pancreatic fibrosis. Gut, 55(1):79-89, 2006.

McKinnon, G.; de Jersey, J.; Shanley, B. \& Ward, L. The reaction of acetaldehyde with brain microtubular proteins: Formation of stable adducts and inhibition of polymerization. Neurosci. Lett., 79(1-2):1638, 1987.

Medina, E. Bases para un nuevo plan sobre alcoholismo en el sector salud. Cuad. Med. Soc., 21(1):84-9, 1980

Meyer, M. J.; Mosely, D. E.; Amarnath, V. \& Picklo, M. J. Sr. Metabolism of 4-hydroxy-trans-2-nonenal by central nervous system mitochondria is dependent on age and NAD+ availability. Chem. Res. Toxicol., 17(9):1272-9, 2004.

Mukamal, K. J. Alcohol consumption and abnormalities of brain structure and vasculature. Am. J. Geriatr. Cardiol., 13(1):22-8, 2004.

Murphy, T. C.; Amarnath, V. \& Picklo, M. J. Sr. Mitochondrial oxidation of 4-hydroxy-2-nonenal in rat cerebral cortex. J. Neurochem., 84(6): 1313-21, 2003.

Nakamura, K.; Iwahashi, K.; Furukawa, A.; Ameno, K.; Kinoshita, H.; Ijiri, I.; Sekine, Y.; Suzuki, K.; Iwata, Y.; Minabe, Y. \& Mori, N. Acetaldehyde adducts in the brain of alcoholics. Arch. Toxicol., 77(10):591-3, 2003. Nanji, A. A.; Jokelainen, K.; Lau, G. K.; Rahemtulla, A.; Tipoe, G. L.;
Polavarapu, R. \& Lalani, E. N. Arginine reverses ethanol-induced inflammatory and fibrotic changes in liver despite continued ethanol administration. J. Pharmacol. Exp. Ther., 299(3):832-9, 2001.

Nieto, N. Ethanol and fish oil induce NFkappaB transactivation of the collagen alpha2(I) promoter through lipid peroxidation-driven activation of the PKC-PI3K-Akt pathway. Hepatology, 45(6):1433-45, 2007.

Nieto, N.; Friedman, S. L. \& Cederbaum, A. I. Cytochrome P450 2E1derived reactive oxygen species mediate paracrine stimulation of collagen I protein synthesis by hepatic stellate cells. J. Biol. Chem., 277(12):9853-64, 2002.

Omary, M. B.; Lugea, A.; Lowe, A. W. \& Pandol, S. J. The pancreatic stellate cell: a star on the rise in pancreatic diseases. J. Clin. Invest., 117(1):50-9, 2007

Phillips, G. B. \& Safrit, H. F. Alcoholic diabetes. Induction of glucose intolerance with alcohol. JAMA, 217(11):1513-9, 1971.

Phillips, P. A.; McCarroll, J. A.; Park, S.; Wu, M. J.; Pirola, R.; Korsten, M.; Korsten, M.; Wilson, J. S. \& Apte, M. V. Rat pancreatic stellate cells secrete matrix metalloproteinases: implications for extracellular matrix turnover. Gut, 52(2):275-82, 2003

Rehm, J.; Baliunas, D.; Borges, G. L.; Graham, K.; Irving, H.; Kehoe, T.; Parry, C. D.; Patra, J.; Popova, S.; Poznyak, V.; Roerecke, M.; Room, R.; Samokhvalov, A. V. \& Taylor, B. The relation between different dimensions of alcohol consumption and burden of disease: an overview. Addiction, 105(5):817-43, 2010a.

Rehm, J.; Kanteres, F. \& Lachenmeier, D. W. Unrecorded consumption, quality of alcohol and health consequences. Drug Alcohol Rev., 29(4):426-36, 2010b.

Rimm, E. B.; Chan, J.; Stampfer, M. J.; Colditz, G. A. \& Willett, W. C. Prospective study of cigarette smoking, alcohol use, and the risk of diabetes in men. B. M. J., 310(6979):555-9, 1995

Roberts, A. J. \& Koob, G. F. The neurobiology of addiction: an overview. Alcohol Health Res. World, 21(2):101-6, 1997.

Ronis, M. J.; Korourian, S.; Blackburn, M. L.; Badeaux, J. \& Badger, T. M. The role of ethanol metabolism in development of alcoholic steatohepatitis in the rat. Alcohol, 44(2):157-69, 2010.

Selby, J. V.; Newman, B.; King, M. C. \& Friedman, G. D. Environmental and behavioral determinants of fasting plasma glucose in women. A matched co-twin analysis. Am. J. Epidemiol., 125(6):979-88, 1987.

Skrzydlewska, E.; Augustyniak, A.; Michalak, K. \& Farbiszewski, R. Green tea supplementation in rats of different ages mitigates ethanol-induced changes in brain antioxidant abilities. Alcohol, 37(2):89-98, 2005.

Sohda, T.; Shimizu, M.; Kamimura, S. \& Okumura, M. Immunohistochemical demonstration of ethanol-inducible P450 2E1 in rat brain. Alcohol Alcohol. Suppl., 1B:69-75, 1993.

Stampfer, M. J.; Colditz, G. A.; Willett, W. C.; Manson, J. E.; Arky, R. A.; Hennekens, C. H. \& Speizer, F. E. A prospective study of moderate alcohol drinking and risk of diabetes in women. Am. J. Epidemiol., 128(3):549-58, 1988.

Stevens, T.; Conwell, D. L. \& Zuccaro, G. Pathogenesis of chronic pancreatitis: an evidence-based review of past theories and recent developments. Am. J. Gastroenterol., 99(11):2256-70, 2004.

Thadani, P. V. \& Truitt, E. B. Jr. Effect of acute ethanol or acetaldehyde administration on the uptake, release, metabolism and turnover rate of norepinephrine in rat brain. Biochem. Pharmacol., 26(12):1147-50, 1977.

Tindberg, N. \& Ingelman-Sundberg, M. Expression, catalytic activity, and inducibility of cytochrome P450 2E1 (CYP2E1) in the rat central nervous system. J. Neurochem., 67(5):2066-73, 1996.

Trudell, J. R.; Ardies, C. M. \& Anderson, W. R. Cross-reactivity of antibodies raised against acetaldehyde adducts of protein with acetaldehyde adducts of phosphatidyl-ethanolamine: possible role in alcoholic cirrhosis. Mol. Pharmacol., 38(5):587-93, 1990.

Trudell, J. R.; Ardies, C. M.; Green, C. E. \& Allen, K. Binding of antiacetaldehyde $\operatorname{IgG}$ antibodies to hepatocytes with an acetaldehydephosphatidylethanolamine adduct on their surface. Alcohol. Clin. Exp. Res., 15(2):295-9, 1991. 
Tuma, D. J. \& Casey, C. A. Dangerous byproducts of alcohol breakdown-focus on adducts. Alcohol Res. Health, 27(4):285-90, 2003.

Upadhya, S. C.; Tirumalai, P. S.; Boyd, M. R.; Mori, T. \& Ravindranath, V. Cytochrome P4502E (CYP2E) in brain: constitutive expression, induction by ethanol and localization by fluorescence in situ hybridization. Arch. Biochem. Biophys., 373(1):23-34, 2000.

Vargas, M. W. Alcohol y alcoholismo. Algunas consideraciones sobre la historia y magnitud del problema en Chile, y de las vías correctas para su solución. Rev. Med. Humanid., 1(3):149-58, 2009.

Wang, H.; Zhang, Y.; Bai, R.; Wang, M. \& Du, S. baicalin attenuates alcoholic liver injury through modulation of hepatic oxidative stress, inflammation and sonic hedgehog pathway in rats. Cell Physiol. Biochem., 39(3):1129-40, 2016.

Wang, M.; McIntee, E. J.; Cheng, G.; Shi, Y.; Villalta, P. W. \& Hecht, S. S. Identification of DNA adducts of acetaldehyde. Chem. Res. Toxicol., 13(11):1149-57, 2000.

Wannamethee, S. G.; Camargo, C. A. Jr.; Manson, J. E.; Willett, W. C. \& Rimm, E. B. Alcohol drinking patterns and risk of type 2 diabetes mellitus among younger women. Arch. Intern. Med., 163(11):1329-36, 2003.

Warner, M. \& Gustafsson, J. A. Effect of ethanol on cytochrome P450 in the rat brain. Proc. Natl. Acad. Sci. U. S. A., 91(3):1019-23, 1994.

Wilson, J. S. \& Apte, M. V. Role of alcohol metabolism in alcoholic pancreatitis. Pancreas, 27(4):311-5, 2003.

Wilson, J. S.; Apte, M. V.; Thomas, M. C.; Haber, P. S. \& Pirola, R. C. Effects of ethanol, acetaldehyde and cholesteryl esters on pancreatic lysosomes. Gut, 33(8):1099-104, 1992.

Wilson, J. S.; Colley, P. W.; Sosula, L.; Pirola, R. C.; Chapman, B. A. \& Somer, J. B. Alcohol causes a fatty pancreas. A rat model of ethanolinduced pancreatic steatosis. Alcohol Clin. Exp. Res., 6(1):117-21, 1982.

Witt, H.; Apte, M. V.; Keim, V. \& Wilson, J. S. Chronic pancreatitis: challenges and advances in pathogenesis, genetics, diagnosis, and therapy. Gastroenterology, 132(4):1557-73, 2007.

World Health Organization. Alcohol. Descriptive Note $N^{\circ} 349$. Nueva York, World Health Organization, 2011.

Yan, S. L.; Wang, Z. H.; Yen, H. F.; Lee, Y. J. \& Yin, M. C. Reversal of ethanol-induced hepatotoxicity by cinnamic and syringic acids in mice. Food Chem. Toxicol., 98(Pt. B):119-26, 2016.

Yip, W. W. \& Burt, A.D. Alcoholic liver disease. Semin. Diagn. Pathol., 23(3-4):149-60, 2006.

Zakhari, S. Overview. Overview: how is alcohol metabolized by the body? Alcohol Res. Health., 29(4):245-54, 2006.

Zelko, I. N.; Mariani, T. J. \& Folz, R. J. Superoxide dismutase multigene family: a comparison of the CuZn-SOD (SOD1), Mn-SOD (SOD2), and EC-SOD (SOD3) gene structures, evolution, and expression. Free Radic. Biol. Med., 33(3):337-49, 2002.

Zhao, M.; Laissue, J. A. \& Zimmermann, A. TUNEL-positive hepatocytes in alcoholic liver disease. A retrospective biopsy study using DNA nick end-labelling. Virchows Archiv., 431(5):337-44, 1997.

Zimatkin, S. M. \& Deitrich, R. A. Ethanol metabolism in the brain. Addict. Biol., 2:387-99, 1997.

Zimatkin, S. M.; Pronko, S. P.; Vasiliou, V.; Gonzalez, F. J. \& Deitrich, R. A. Enzymatic mechanisms of ethanol oxidation in the brain. Alcohol. Clin. Exp. Res., 30(9):1500-5, 2006.

Zimatkin, S. M.; Rout, U. K.; Koivusalo, M.; Bühler, R. \& Lindros, K. O. Regional distribution of low-Km mitochondrial aldehyde dehydrogenase in the rat central nervous system. Alcohol. Clin. Exp. Res., 16(6):11627, 1992.

Zintzaras, E.; Stefanidis, I.; Santos, M. \& Vidal, F. Do alcohol-metabolizing enzyme gene polymorphisms increase the risk of alcoholism and alcoholic liver disease? Hepatology, 43(2):352-61, 2006.

\author{
Corresponding author: \\ Dr. Mariano del Sol \\ Centro de Excelencia en Estudios Morfológicos y Quirúrgi- \\ $\cos ($ CEMyQ) \\ Facultad de Medicina \\ Universidad de La Frontera \\ Avenida Francisco Salazar 01145 \\ Casilla 54-D \\ Temuco \\ Chile
}

Teléfono: (56) (45) 2325571

E-mail: mariano.delsol@ufrontera.cl

Received: 16-05-2017

accepted: 14-06-2017 